\title{
EFFECT OF WASTE FIBRE MATERIAL ON ENGINEERING PROPERTIES OF RED SOIL
}

\author{
Niha Lahkar ${ }^{1}$, Priyanka Das ${ }^{2}$, Madhurya Das ${ }^{3}$, Yudhajit Dey ${ }^{4}$ \\ Bachelor of Technology ${ }^{1,2,3}$, Assistant Professor ${ }^{4}$, \\ Royal School of Engineering and Technology
}

\begin{abstract}
This paper aims to check the effectiveness of waste fibre material on the engineering properties of red soil. The main purpose is to select some waste fibre materials which helps in enhancing the engineering properties of soil. Soil reinforcement has been introduced into the field of geotechnical engineering for many years in order to improve the properties of ground soil in specific engineering projects. Considering these, a series of tests were performed with red soil with waste fibre as reinforcement at various percentage content to find out its effects on the soil and to find whether the particular soil- reinforcement combination is useful.
\end{abstract}

Keywords - Waste fibre material, red soil, reinforcement

\section{INTRODUCTION}

Stabilization of soil is the alteration of engineering properties of soil, thus increasing the strength of soil. Soil stabilization can be utilized on roadways, pavements, site development projects etc. Stabilization can be used to treat a wide range of subgrade materials varying from expansive clays to granular materials. With growing environmental awareness, new rules and legislation scientists and engineers are forced to seek new materials which are eco-friendly in nature. Hence, the attention of the research community is focused towards finding an eco-friendly material which can give high performance at affordable costs. Natural fiber composites are one such kind of materials. The usage of natural fibers on the composites is well-known, because of its inherited qualities such as renewable, biodegradability etc. Further they are available in abundance, nontoxic and nonhazardous in nature, naturally recyclable, less expensive. Sponge gourd or The usage of fibers as reinforcement in composites is not new; numerous surveys and studies on properties and behavior of natural fiber-reinforced composites have been carried out to a great extent. They generally have a thin organic and inorganic mineral layer overlaying a yellowish brown layer resting on the alluvial deposits.

Red soil is derived from weathering of ancient metamorphic rock of the Deccan plateau. Red soil is any of a group of soil the grow in a humid temperature, moist climate under deciduous and mix forests and that have raw material. Thin organic layers overlaying a yellowish brown leached deposit resting on an alluvial. Their color is mostly ferric oxides occurring a slight coatings a slight coatings on the soil particle through the iron oxide arise as hematite as hydrous ferric oxide, the color is red and hen it happen in the hydrate system as limonite the soil become to be yellow color.

\section{METHODOLOGY}

\subsection{Selection of Fiber Materials}

2.1.1 Loofah sponge: Luffa is a genus of tropical and subtropical vines in the cucumber family. Loofah sponge exhibit remarkable stiffness, strength and energy absorption capacity that are comparable to some other fibers. The loofah sponge is a dried out gourd. These are easily available and not expensive.

2.1.2 Corn Husk: Corn husk are the outer coverings of an ear of corn. Corn husk refers to the leafy outer covering of an ear of maize (corn) as it grows on the planet. It is the protective outer covering which is sun, air or oven dried.

The usage of fibers as reinforcement in composites is not new; numerous surveys and studies on properties and behavior of natural fiber-reinforced composites have been carried out to a great extent. However not much studies on using the loofah sponge and corn husk as a reinforcing material has been done, very few references are available.

\subsection{Preparation of Fiber Materials}

The fiber materials to be used are cornhusk and loofah sponge. Both the materials are cut out in the form of strips of $1 \mathrm{~cm} \times 2 \mathrm{~cm}$ as shown in figure 


\section{International Journal of Engineering Applied Sciences and Technology, 2021 \\ Vol. 5, Issue 9, ISSN No. 2455-2143, Pages 221-228 \\ Published Online January 2021 in IJEAST (http://www.ijeast.com)}

below. These strips are then to be oriented and mixed with soil. Both the fibers are to be singly reinforced with the soil in the proportion of $2.5 \%, 3.75 \%$ and $5 \%$ by weight of soil. After performing the tests on both the singly reinforced soils i.e. soil reinforced with cornhusk and soil reinforced with loofah sponge, the composite of both the fibers are to be used as reinforces in the proportion of 50-50\%, 70-30\% and $80-20 \%$ of $2.5 \%, 3.75 \%$ and $5 \%$ by weight of soil. Apart from 50-50\% composite for the rest proportions i.e. $70-30 \%$ and $80-20 \%$, the higher percentage will taken of that fiber which will be giving better results on the tests performed for singly reinforced soils.
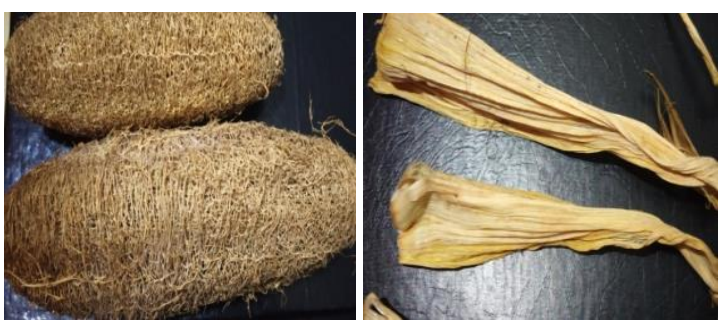

Fig 1.1: Loofah Sponge

Fig 1.2: Corn husk

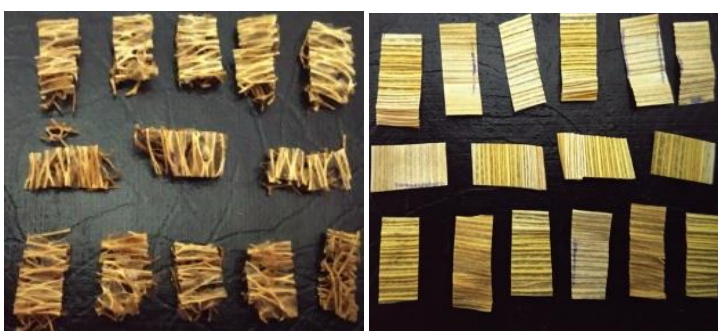

Fig 1.3: Strips of loofah sponge and corn husk

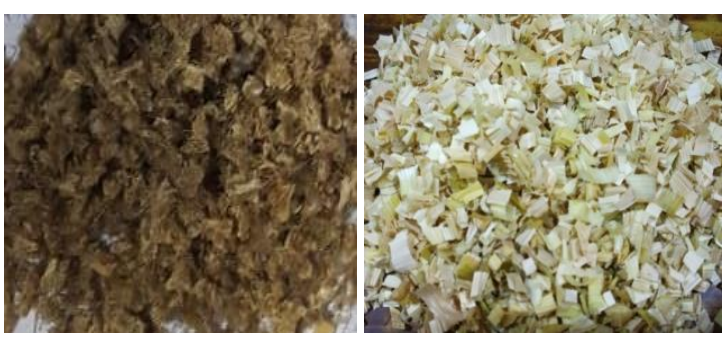

Fig 1.4: Preparation of fibers

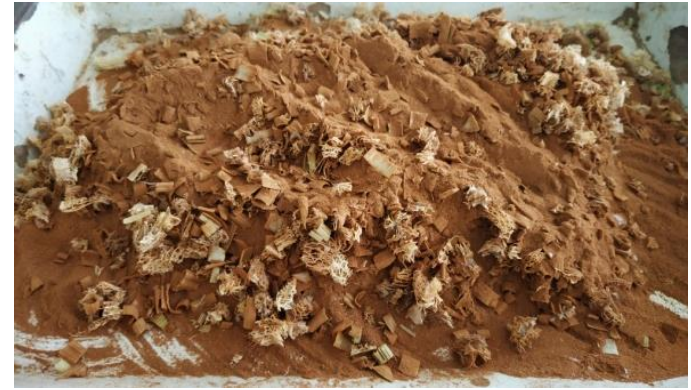

Fig 1.5: Soil mixed with fibers

2.3The following set of experiments are intended to be carried out :

1. Core Cutter Test

2. Atterberg's Limit:
i. Liquid Limit
ii. Plastic Limit

3. Specific Gravity Test

4. Standard Proctor Test

5. Unconfined Compression Test

\section{RESULTS \& DISCUSSION}

\subsection{Experimental observations of normal soil:}

\subsubsection{Atterberg's Limits}

Table 3.1 For normal soil

\begin{tabular}{|l|l|}
\hline Parameters & Values \\
\hline Liquid Limit & $46 \%$ \\
\hline Plastic Limit & $31.23 \%$ \\
\hline Plasticity Index & $\mathbf{1 4 . 7 7 \%}$ \\
\hline
\end{tabular}

\subsubsection{Standard Proctor Compaction Test}

Table 3.2For normal soil

\begin{tabular}{|l|l|}
\hline 1) Volume of mould (cc) & 958.21 \\
\hline 2) Weight of mould (g) & 2002 \\
\hline 3) Weight of sample taken $(\mathrm{g})$ & 2500 \\
\hline 4)Maximum Dry Unit Weight $\left(\mathrm{kN} / \mathrm{m}^{3}\right)$ & 14.58 \\
\hline 5) Optimum Moisture Content $(\%)$ & 29.41 \\
\hline
\end{tabular}

3.2 Experimental observations of soil mixed with loofah sponge: 
International Journal of Engineering Applied Sciences and Technology, 2021

Vol. 5, Issue 9, ISSN No. 2455-2143, Pages 221-228

Published Online January 2021 in IJEAST (http://www.ijeast.com)

\subsubsection{Atterberg's Limits}

Table 3.3 For soil mixed with $2.5 \%$ of Loofah

\begin{tabular}{|l|l|}
\hline Parameters & Values \\
\hline Liquid Limit & $41.11 \%$ \\
\hline Plastic Limit & $28.31 \%$ \\
\hline Plasticity Index & $\mathbf{1 2 . 8 \%}$ \\
\hline
\end{tabular}

Table 3.4 For soil mixed with $3.75 \%$ of Loofah

\begin{tabular}{|l|l|}
\hline Parameters & Values \\
\hline Liquid limit & $36.84 \%$ \\
\hline Plastic limit & $28.31 \%$ \\
\hline Plasticity Index & $\mathbf{8 . 5 3 \%}$ \\
\hline
\end{tabular}

Table 3.5 For soil mixed with $5 \%$ of Loofah

\begin{tabular}{|l|l|}
\hline Parameters & Values \\
\hline Liquid limit & $32.77 \%$ \\
\hline Plastic limit & $28.31 \%$ \\
\hline Plasticity Index & $\mathbf{4 . 4 6 \%}$ \\
\hline
\end{tabular}

3.3 Experimental observation of soil mixed with corn husk

\subsubsection{Atterberg's Limits}

Table 3.6 For soil mixed with $2.5 \%$ of Cormhusk

\begin{tabular}{|l|l|}
\hline Parameters & Values \\
\hline Liquid limit & $38.74 \%$ \\
\hline Plastic limit & $28.97 \%$ \\
\hline Plasticity Index & $\mathbf{9 . 7 6 \%}$ \\
\hline
\end{tabular}

Table 3.7 For soil mixed with $3.75 \%$ of Cornhusk

\begin{tabular}{|l|l|}
\hline Parameters & Values \\
\hline Liquid limit & $36.31 \%$ \\
\hline Plastic limit & $28.97 \%$ \\
\hline Plasticity Index & $\mathbf{7 . 4 4 \%}$ \\
\hline
\end{tabular}

Table 3.8 For soil mixed with 5\% of Cornhusk

\begin{tabular}{|l|l|}
\hline Parameters & Values \\
\hline Liquid limit & $33.97 \%$ \\
\hline Plastic limit & $28.97 \%$ \\
\hline Plasticity Index & $\mathbf{5 \%}$ \\
\hline
\end{tabular}

\subsubsection{Standard Proctor Test}

Table 3.9 Standard Proctor Test (cornhusk 5\%)

\begin{tabular}{|l|l|}
\hline 1) Volume of mould (cc) & 958.21 \\
\hline 2) Weight of mould $(\mathrm{g})$ & 2002 \\
\hline 3) Weight of sample taken $(\mathrm{g})$ & 2500 \\
\hline 4)Maximum Dry Unit Weight $\left(\mathrm{kN} / \mathrm{m}^{3}\right)$ & 12.44 \\
\hline 5) Optimum Moisture Content $(\%)$ & 42.86 \\
\hline
\end{tabular}

3.4 Experimental observation of soil mixed with $\mathbf{5 0 - 5 0 \%}$ of composite

\subsubsection{Atterberg's Limits}

Table 3.10 For soil mixed with $2.5 \%$ of Composite

\begin{tabular}{|l|l|}
\hline Parameters & Values \\
\hline Liquid limit & $38.27 \%$ \\
\hline Plastic limit & $25 \%$ \\
\hline Plasticity Index & $\mathbf{1 3 . 2 7 \%}$ \\
\hline
\end{tabular}

Table 3.11 For soil mixed with $3.75 \%$ of Composite

\begin{tabular}{|l|l|}
\hline Parameters & Values \\
\hline Liquid limit & $32.77 \%$ \\
\hline Plastic limit & $25 \%$ \\
\hline Plasticity Index & $\mathbf{7 . 7 7 \%}$ \\
\hline
\end{tabular}

Table 3.12 For soil mixed with 5\% of Composite

\begin{tabular}{|l|l|}
\hline Parameters & Values \\
\hline Liquid limit & $28.69 \%$ \\
\hline Plastic limit & $25 \%$ \\
\hline Plasticity Index & $\mathbf{3 . 6 9 \%}$ \\
\hline
\end{tabular}

\subsubsection{Standard Proctor Test}

Table 3.13 Standard Proctor Test (Composite 50$50 \%)$

\begin{tabular}{|l|l|}
\hline 1) Volume of mould $(\mathrm{cc})$ & 958.21 \\
\hline 2) Weight of mould $(\mathrm{g})$ & 2002 \\
\hline 3) Weight of sample taken $(\mathrm{g})$ & 2500 \\
\hline 4)Maximum Dry Unit Weight $\left(\mathrm{kN} / \mathrm{m}^{3}\right)$ & 12.06 \\
\hline 5) Optimum Moisture Content $(\%)$ & 50 \\
\hline
\end{tabular}

3.5 Experimental observations of soil mixed with 70-30\% of composite

\subsubsection{Atterberg's Limits}

Table 3.14 For soil mixed with $2.5 \%$ of Composite 
International Journal of Engineering Applied Sciences and Technology, 2021

Vol. 5, Issue 9, ISSN No. 2455-2143, Pages 221-228

Published Online January 2021 in IJEAST (http://www.ijeast.com)

\begin{tabular}{|l|l|}
\hline Parameters & Values \\
\hline Liquid limit & $33.97 \%$ \\
\hline Plastic limit & $24.52 \%$ \\
\hline Plasticity Index & $\mathbf{9 . 4 5 \%}$ \\
\hline
\end{tabular}

\begin{tabular}{|l|l|}
\hline 1) Volume of mould (cc) & 958.21 \\
\hline 2) Weight of mould (g) & 2058 \\
\hline 3) Weight of sample taken $(\mathrm{g})$ & 2500 \\
\hline 4)Maximum Dry Unit Weight $\left(\mathrm{kN} / \mathrm{m}^{3}\right)$ & 11.68 \\
\hline 5) Optimum Moisture Content $(\%)$ & 44.44 \\
\hline
\end{tabular}

Table 3.15 For soil mixed with $3.75 \%$ of Composite

\section{EXPERIMENTAL RESULTS}

\begin{tabular}{|l|l|}
\hline Parameters & Values \\
\hline Liquid limit & $28.97 \%$ \\
\hline Plastic limit & $24.52 \%$ \\
\hline Plasticity Index & $\mathbf{4 . 4 5 \%}$ \\
\hline
\end{tabular}

\subsection{Experimental results of normal soil}

\subsubsection{Liquid Limit}

Table 3.16 Forsoil mixed with 5\% of Composite

\begin{tabular}{|l|l|}
\hline Parameters & Values \\
\hline Liquid limit & $28.04 \%$ \\
\hline Plastic limit & $24.52 \%$ \\
\hline Plasticity Index & $\mathbf{3 . 5 2 \%}$ \\
\hline
\end{tabular}

3.6 Experimental observation of soil mixed with $\mathbf{8 0 - 2 0 \%}$ of composite

\subsubsection{Atterberg's Limits}

Table 3.17 For soil mixed with $2.5 \%$ of Composite

\begin{tabular}{|l|l|}
\hline Parameters & Values \\
\hline Liquid limit & $28.97 \%$ \\
\hline Plastic limit & $19.76 \%$ \\
\hline Plasticity Index & $\mathbf{9 . 2 1 \%}$ \\
\hline
\end{tabular}

Table 3.18 For soil mixed with $3.75 \%$ of Composite

\begin{tabular}{|l|l|}
\hline Parameters & Values \\
\hline Liquid limit & $24.52 \%$ \\
\hline Plastic limit & $19.76 \%$ \\
\hline Plasticity Index & $\mathbf{4 . 7 6 \%}$ \\
\hline
\end{tabular}

Table 3.19 For soil mixed with 5\% of Composite

\begin{tabular}{|l|l|}
\hline Parameters & Values \\
\hline Liquid limit & $21.29 \%$ \\
\hline Plastic limit & $19.76 \%$ \\
\hline Plasticity Index & $\mathbf{1 . 5 3 \%}$ \\
\hline
\end{tabular}

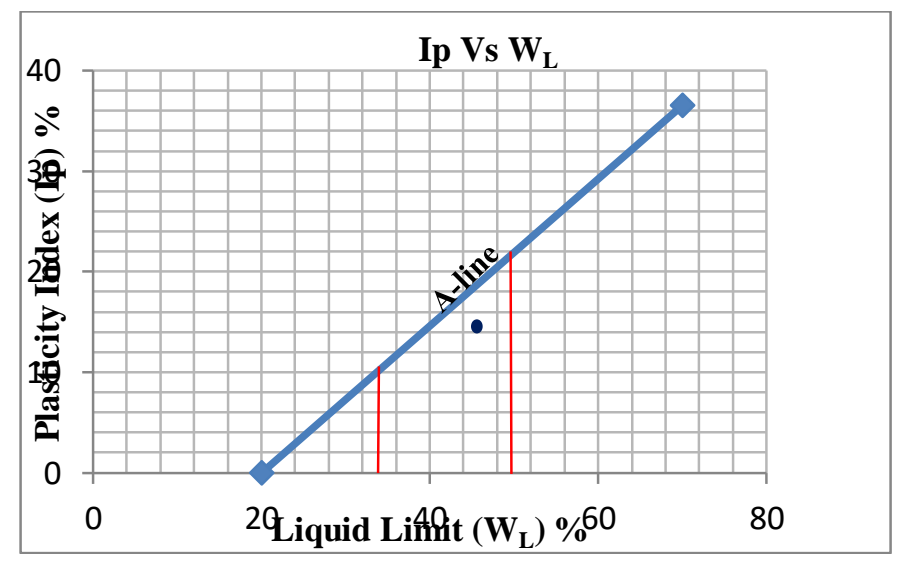

Fig 4.2: Plasticity Index

\subsubsection{Standard Proctor Test}

Fig 4.1: Water Content Vs No. of Blows

\subsubsection{Plasticity Index}

\subsubsection{Standard Proctor Test}

Table 3.20 Standard Proctor Test (Composite 8020\%) 


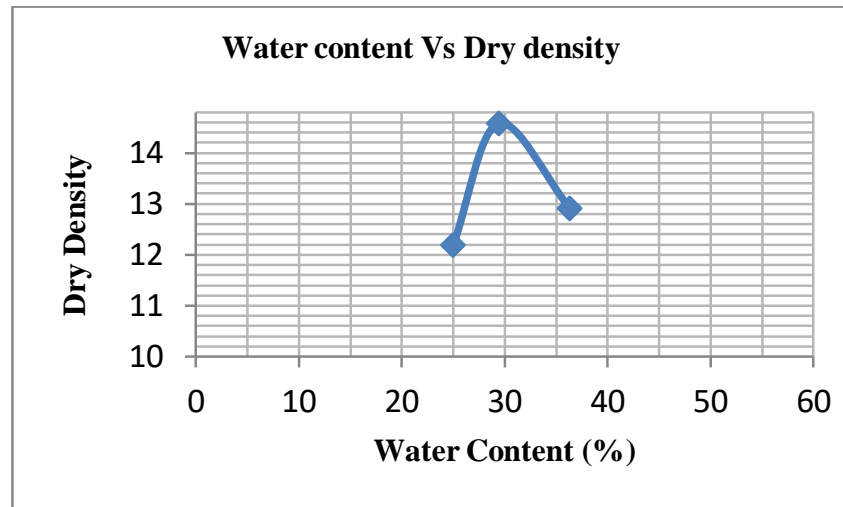

Fig 4.3: W/C Vs DryDensity

\subsubsection{Unconfined Compression Test}

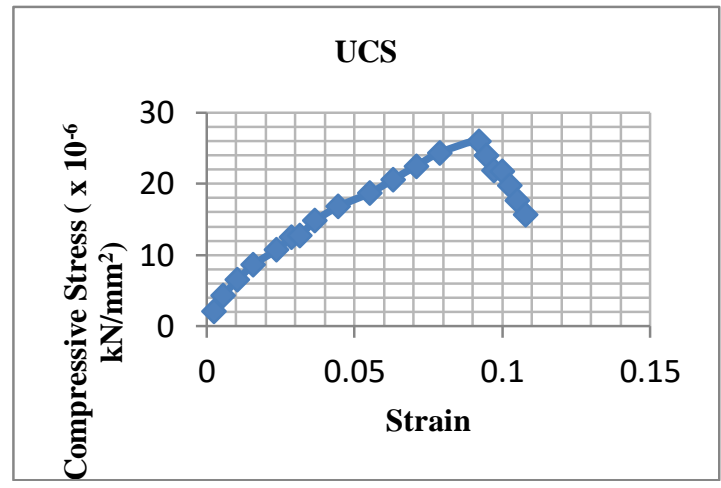

Fig 4.4: Stress Vs Strain

4.2 Experimental results of soil mixed with Loofah Sponge

\subsubsection{Liquid Limit}

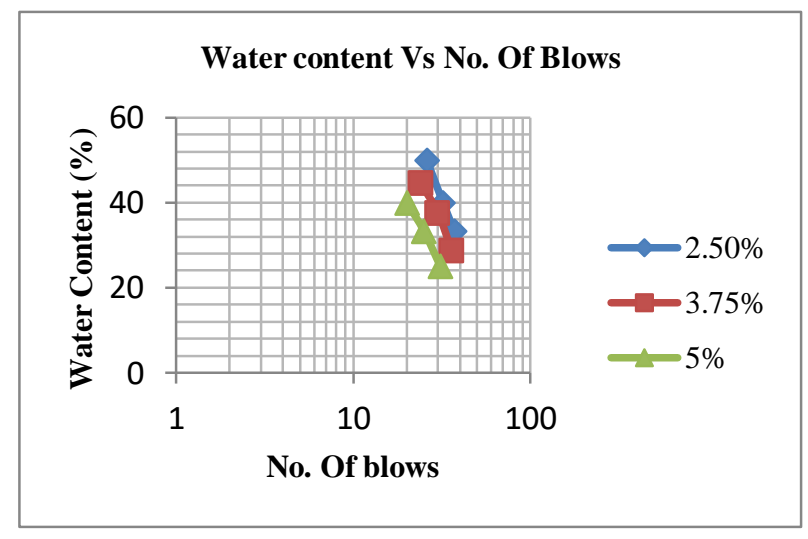

Fig 4.5: Water Content Vs No. of Blows

\subsection{Experimental results of soil mixed with Corn Husk}

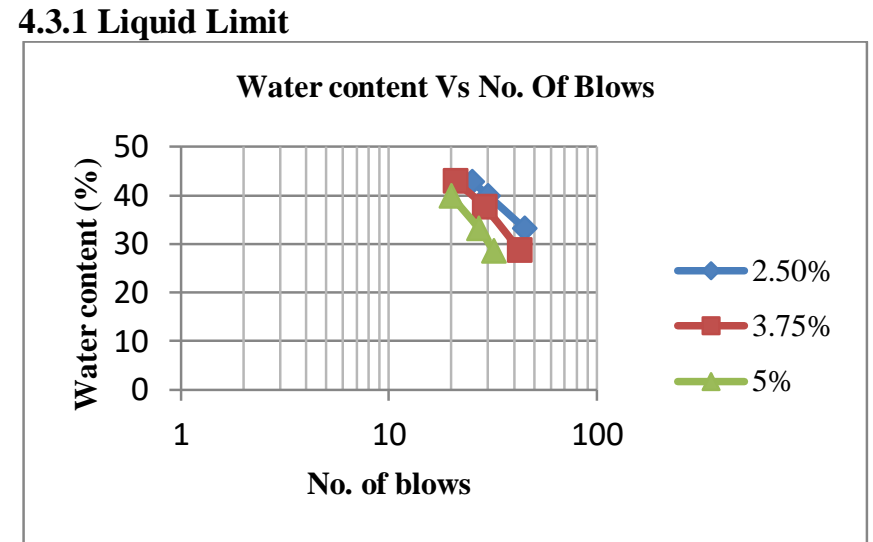

Fig 4.6: Water Content Vs No. of Blows

\subsubsection{Standard Proctor Test}

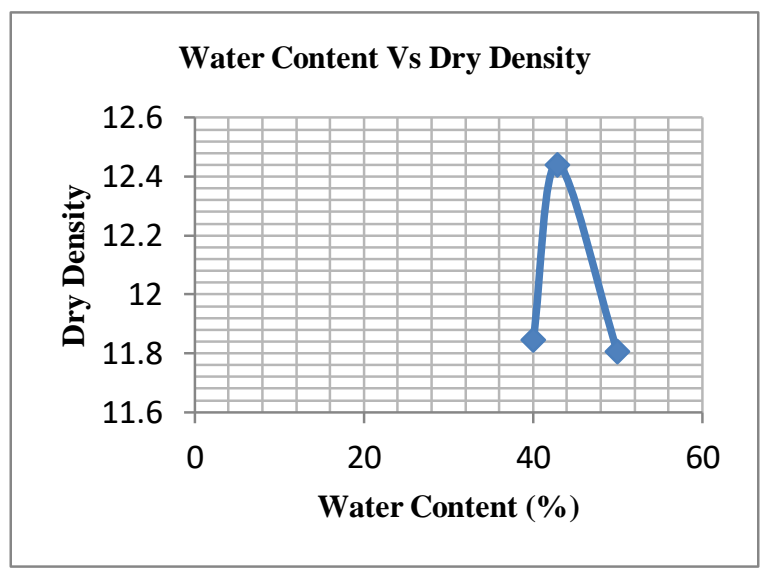

Fig 4.7: Water Content Vs Dry Density

\subsubsection{Unconfined Compression Test}

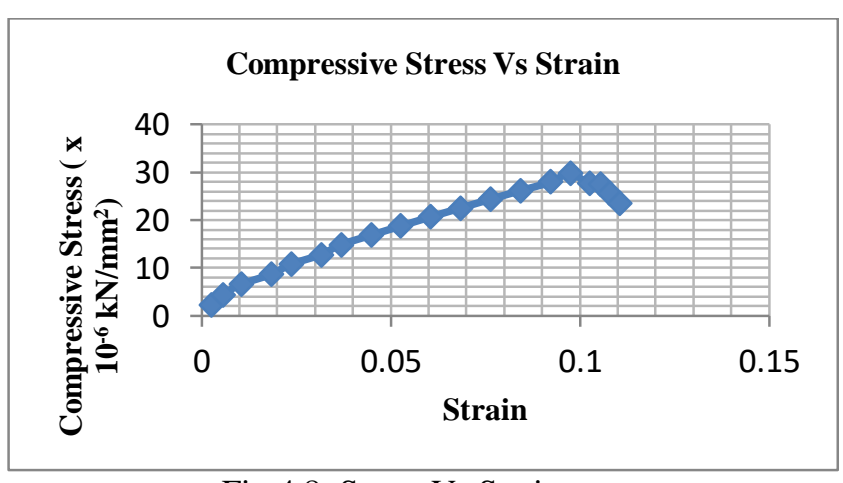

Fig 4.8: Stress Vs Strain

4.4 Experimental results of soil mixed with $50-50 \%$ of composite

\subsubsection{Liquid Limit}




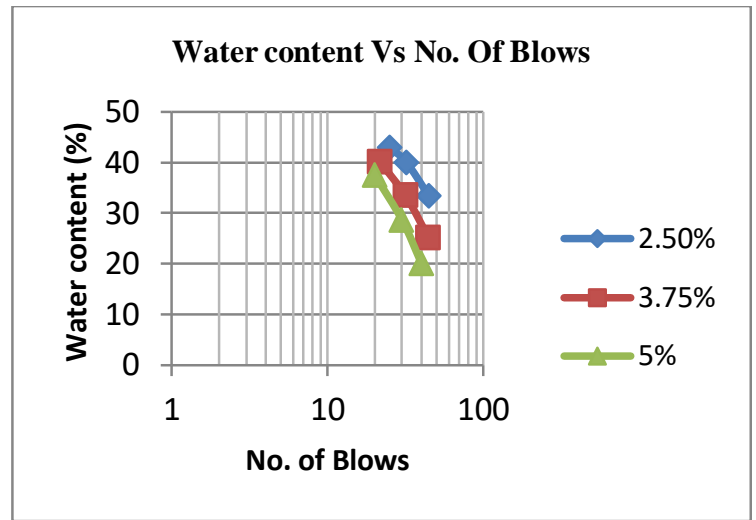

Fig 4.9: Water content Vs No. of Blows

\subsubsection{Standard Proctor Test}

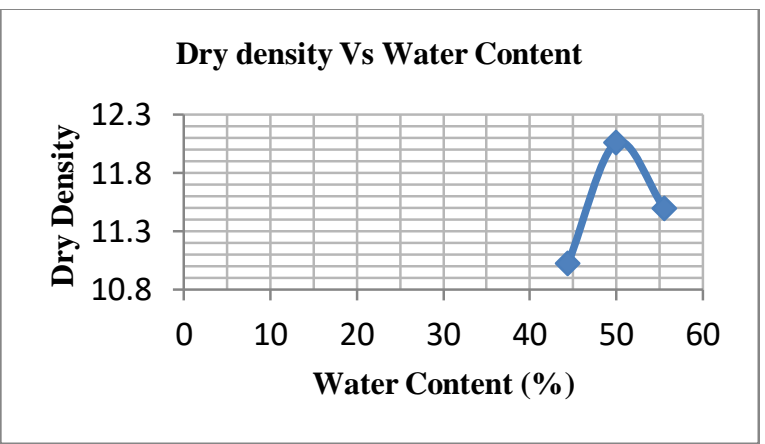

Fig 4.10: Dry Density Vs Water Content

\subsubsection{Unconfined Compression Test}

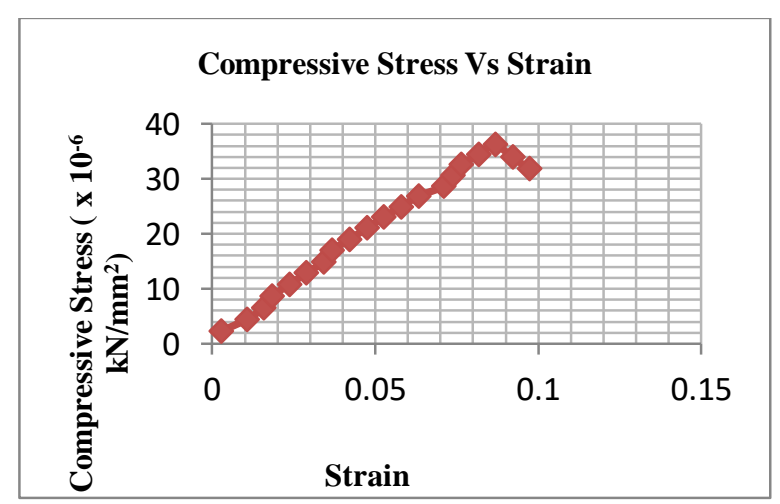

Fig 4.11: Stress Vs Strain

\subsection{Comparison}

4.5.1 In terms of Plasticity Index

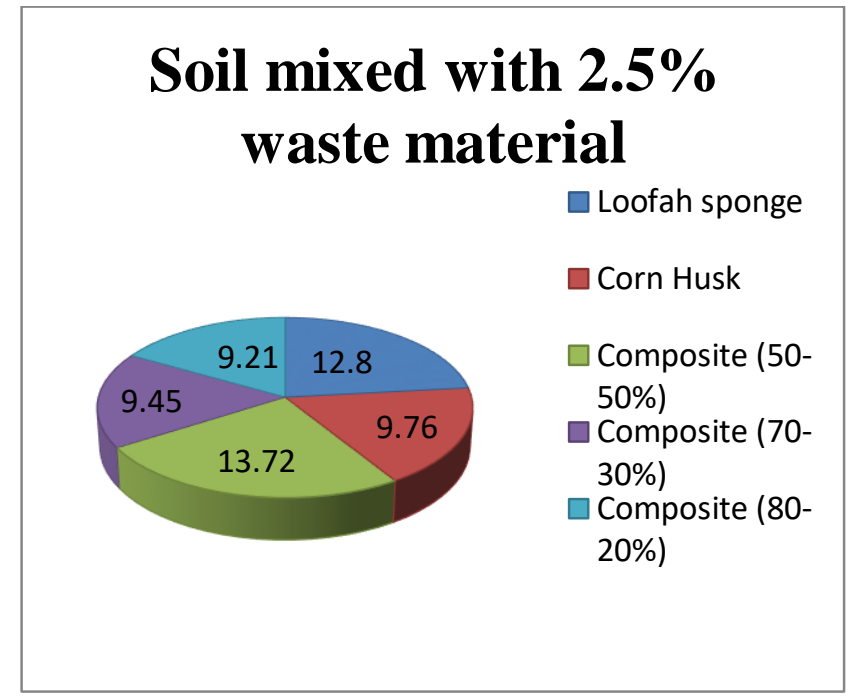

Fig 4.12: Soil mixed with $2.5 \%$ fiber material

\section{Soil mixed with $3.75 \%$ waste material}

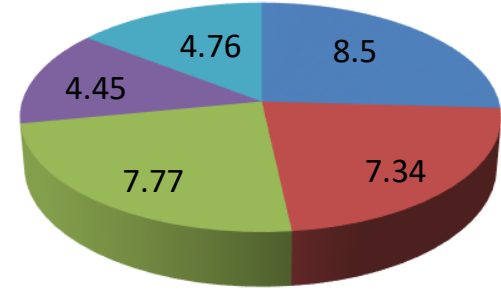

$$
\begin{aligned}
& \text { Loofah sponge } \\
& \text { Corn Husk } \\
& \text { Composite (50- } \\
& 50 \% \text { ) } \\
& \text { Composite (70- } \\
& 30 \% \text { ) } \\
& \text { Composite (80- } \\
& 20 \%)
\end{aligned}
$$

Fig 4.13: Soil mixed with $3.75 \%$ waste material

\section{Soil mixed with $5 \%$ waste material}

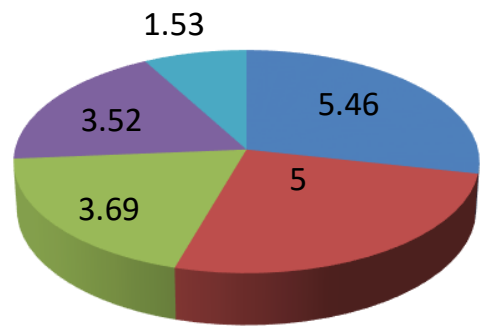

$$
\begin{aligned}
& \text { Loofah sponge } \\
& \text { Corn Husk } \\
& \text { Composite (50- } \\
& 50 \% \text { ) } \\
& \text { Composite (70- } \\
& 30 \% \text { ) } \\
& \text { Composite (80- } \\
& 20 \% \text { ) }
\end{aligned}
$$

Fig 4.14: Soil mixed with 5\% waste material 


\section{International Journal of Engineering Applied Sciences and Technology, 2021 \\ Vol. 5, Issue 9, ISSN No. 2455-2143, Pages 221-228 \\ Published Online January 2021 in IJEAST (http://www.ijeast.com)}

\subsubsection{In terms of Unconfined Compressive Strength}

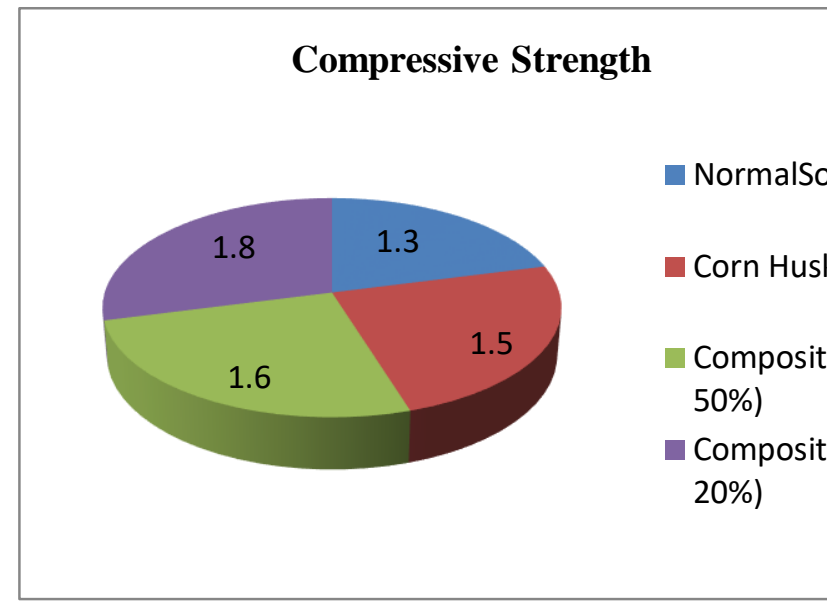

Fig 4.15: Unconfined Compressive Strength

\section{CONCLUSION}

On the basis of experimental observations and results, the following conclusions are drawn:

1. The gradation curve is plotted between plasticity index and liquid limit and the soil is classified as MI (Silt Intermediate) i.e. silts with moderate plastic.

2. In terms of Plasticity Index:

Corn husk is better than loofah sponge

Equal distribution of the composite material i.e. corn husk + looofah sponge (50-50\%) gave better results than corn husk $(5 \%)$ mixed with soil.

Unequal distribution of the composite material (70$30 \%$ ) mixed with soil showed better results than soil mixed with $2.5 \%, 3.75 \%, 5 \%$ corn husk.

The soil mixed with $80-20 \%$ of composite showed better results than soil mixed with corn husk alone.

At $3.75 \%$ of unequal distribution of composite (70$30 \%$ ) was found to be better than $80-20 \%$. But at $2.5 \%$ and $5 \%, 80-20 \%$ showed better result than 70 $30 \%$ in terms of plasticity index.

3. In terms of Unconfined Compressive Strength:

Soil mixed with corn husk shows higher compressive strength normal soil.

Soil mixed with $50-50 \%$ of composite material shows higher compressive strength than soil mixed with corn husk alone.

Soil mixed with $80-20 \%$ of composite material shows highest value of compressive strength among all.

\section{FUTURE SCOPE}

These waste fiber materials can be used to stabilize other soil type other than red soil. Red soil can also be stabilized using other waste fiber materials. Instead of raw waste fiber material, ashes of the waste fiber material can be used. Percentages of the waste fiber materials can be varied. The amount of waste fiber materials generated nowadays is very high. The usage of these waste fibre materials can minimize the amount of waste generated.

\section{REFERENCES}

1. A. Dinesh., G. Ramya, S. Gokilavani, (2017), Stabilization of soil by using solid waste - A review, International Journal of Engineering development and research, Volume 5, issue 3, ISSN: 2321-9939

2. Bureau of Indian Standards(1970) Classification and Identification of Soil for General Engineering Purposes, IS 1498,New Delhi, India

3. Hanifi Canakcia, Fatih Celika, Mohammed O. A. Bizneb , Media O. A. Bizneb (2016), Stabilization of Clay with Using Waste Beverage Can, Procedia Engineering 161 ( 2016 ) $595-599$

4. Kumari Bandna, Rattan Jasvir S, Sonthwal Vinod k (2016), Soil Stabilization By Using Waste Material : A Review, International Journal of Engineering Science Invention Research \& Development; Vol. III, Issue I, e-ISSN: 2349-6185

5. Mittal Anupam, Singh Mandeep (2014), A Review On The Soil Stabilization With Waste Materials, International Journal of Engineering Research and Applications (IJERA) ISSN: 2248-9622

6. M. Vasanth, P. Muthupriya,S. Prasanth, S. Sathish kumar,S. Sandeep (2017), Soil Stabilization by using Industrial Waste Material as a Stabilizer, International Journal of Chem.Tech Research CODEN (USA): IJCRGG, ISSN: 0974-4290, ISSN(Online):2455-9555 Vol.10 No.8, pp 431-438

7. Pal Shish, Sodhi Navdeep Singh, Sonthwal Vinod Kumar (2017), Soil Strengthening Using Waste Materials, International Research Journal of Engineering and Technology (IRJET), Volume: 04 Issue: 12, ISSN: 2395-0056

8. Punmia B.C. 2007, 'Soil Mechanics \& Foundation', Laxmi Publications

9. Ranjan Gopal \& A.S.R Rao, 'Basic and Applied Soil Mechanics', New Age International Publishers. 
10. Salimi, K. and Ghzavi, M.: (2019) Soil reinforcement and slope stabilisation using recycled waste plastic sheets.

11. S. A. Naeini and S. M. Sadjadi,(2008), "Effect of Waste Polymer Materials on Shear Strength of Unsaturated Clays", EJGE Journal, Vol 13, Bund $\mathrm{k},(1-12)$

12. Sharma, R.: (2017) Laboratory study on stabilisation of clayey soil with cement kiln dust and fibre. J. Geotech. Geoenviron. Eng. 35, 2291-2302

13. Yetimoglu, T., Inanir, M., Inanir, O.E., (2005) A study on bearing capacity of randomly distributed fiber-reinforced sand fills overlying soft clay. Geotextiles and Geomembranes 23 (2), 174-183. 